\title{
Agropolitan Development in Merapi Disaster Affected Areas
}

\author{
Sartono $^{1}$, Iwan Hermawan ${ }^{2, *}$, Alfi Maghfuriyah ${ }^{1}$ \\ ${ }^{1}$ Accounting, State Polytechnic of Semarang, Jl. Prof Sudharto, Tembalang, Semarang, Jawa Tengah 50275 \\ ${ }^{2}$ Business Administration, State Polytechnic of Semarang, Jl. Prof Sudharto, Tembalang, Semarang, Jawa Tengah 50275
}

\begin{abstract}
Magelang Regency is a strategic city in Central Java. The regency has famous tourist destination objects such as Borobudur Temple, besides the fertile climate and soil conditions are an invaluable asset to support agribusiness development. The position of the boundary line between the city area roomates becomes the product market and the village that the production buffer zone may be developed into a competitive Agropolitan region. The obstacles that arise are Magelang Regency is the affected area of Mount Merapi activity, in addition to causing fertility in agricultural land, and the tectonic earthquake eruption become obstacles to the development of potential areas of Merapi disaster, due to the high of physical hazards such as infrastructure damage. The direction of this paper is to look for potential Agropolitan location references with the guarantee of infrastructure service support, the disaster zone equality into a node that connects the area of agribusiness-producing regions in all regency in Magelang regency. The LQ and KS methods are used to bridge the analysis studies in this paper.
\end{abstract}

Keywords: Agropolitan Area, Disaster Zone, Mount Merapi, Magelang Regency

\section{Introduction}

Magelang has potential competitive to Agropolitan City. Magelang Regency and tourist destinations are scattered in almost all areas in Magelang made as one of the cities that many a tourist destination both locally and overseas. During this time a tourist destination Magelang regency focused on the temple and nature tourism, while tourism development in agropolitan still need to be developed. Besides the temple and nature, Magelang also has some culinary as ecotourism products such Gethuk, Kupat Tahu, Wedang Kacang, Sego Godog, Mangut Ikan Beong, and more potential for ecotourism culinary fringes that can be enjoyed along the way in Magelang regency with 213 food products has had a number of food Industry of Household[1]. Magelang is one food producer in Central Java province. The food commodities consist of rice, corn, yams, cassava and peanuts. Yields of rice in 2015 in Magelang regency of 1195.152 tons, 3148.040 tons of corn, 3963.968 tons of cassava, 3465.493 tons of yams and 597.000 tons of peanuts ${ }^{2}$. The centers of food commodities are in sub Ngablak, Muntilan, Bandongan, and Tegalrejo. In addition except producing food, Magelang also become centers of agribusiness in Central Java province. Agribusiness in Magelang Regency includes Food crops, vegetables and seasonal fruit, fruit, various herbs and ornamental plants with the condition of the buffer zone coconut, coffee robusta, clove, tobacco, and sugar cane[2]. The main market sellers of staples in Magelang Regency is Muntilan as a center of trades and services for the people of Magelang. Muntilan market is located in $10 \mathrm{~km}$ from the capital regency of Magelang, Mungkid and $25 \mathrm{Km}$ from

*Corresponding author: iwanpolines@gmail.com
Yogyakarta also as well as the province on track linking the city of Semarang, Magelang and Yogyakarta[2]. Physical hazard of Magelang is very high because it is vulnerable to a disaster such as an earthquake volcano, hot clouds and volcanic ash. Post-event occurrence of hazards that trigger a disaster, there are groups of people who saved and survived. The eruption of Mount Merapi on 26 October 2010 led to a series of natural phenomena, such as heat clouds, lava, and ash, which brought disaster to the people living around it $[3,4]$.

\section{Methodology}

Data used contains the good harvest of food commodities and commodity vegetables and fruits. Methods of data collection in this study using literature review and documentation techniques. The research was conducted in the Magelang Regency, Central Java. Method of research approach used in this research are Location Quotient (LQ) and Specialization Quotients (KS)[5].

\section{Discussion}

The series of Merapi eruption in October and November 2010 is considered as the largest eruption since the eruption of 1872. Losses of resources (land, water, plants and animals) are also quite large, especially in the agricultural sector's losses reached IDR 5.821 trillion[6]. A loss is felt by farmers with pondoh businesses, farms (dairy cows, beef cattle and buffalo, sheep, goat, and poultry), horticulture and other food crops such as corn and rice. After the eruption, Merapi eruption perceived impact on the viability of social and economic life of the people living around the slopes of Mount Merapi. Before the eruption of 2010, the 
economic activities of the local community relies on agricultural activities by utilizing the natural resources provided by the environment volcano, such as dairy farmers, farmers and sand miners. The threats of agricultural lands in support of agricultural activities not only from land conversion, but also caused by natural disasters that frequently hit Indonesia. According to data obtained by researchers from the Department of National Disaster Management (known as BNPB), for the period from January 1, 2014 to November 30, 2014 there has been a number of disasters that cause as much damage to land 57,958.2 hectares[7]. These conditions resulted in the distribution of products agribusiness of farmers to markets is also hampered because of transportation is also inhibited. A crucial aspect of this phenomenon is redefining the market as a central location that is more capable agropolitan as Merapi disaster. Process for rehabilitation and reconstruction, starting from the clean up area from disaster waste following by rehabilitation and reconstruction, including redesign of the location these center of market become a strategic to provide assuredness where food and disaster mitigation when it happen.

Table LQ agricultural products used as a buffer in case of disaster. LQ $>1$ indicates that the commodity becomes the base of featured products in each region. Commodities have a comparative advantage, the result is not only able to meet the needs in the immediate area but also can be exported to other regions. Production of rice increased by $6.09 \%$ from 2014 when total rice harvest in 2014 amounted to 345,883 tons increasing to 366,981 tons in 2015 . Corn increased by $6.76 \%$ from 2014, which in 2014 amounted to 62,869 tons of corn production increased to 67,124 tons in 2015 . But the rise in the number of rice and corn production in contrast to the decline in production of cassava in Magelang. Cassava production amounted to 48,095 tons decreased by $23.27 \%$ in 2015 to 36,899 tons (2014). The decline also occurred in the production of yams which in the year 2015 decreased by $23.25 \%$ to 21,940 tons in 2015 from 28,590 tons in 2014.

Magelang Regency as one of the agricultural base in Indonesia have a variety of potential agricultural output as a supporter of tourism (ecotourism). Each region has a superior product both as each seed zone and a buffer zone agropolitan basis. Thus, can be lowered by the addition of new agropolitan concept leading tourist attraction and processed products derived in Magelang.

The data shows the sub-regency of Windusari profile that has reliability as buffer crops as well as fruits and vegetables, with LQ and KS more than one, which means there are 13 commodities from agricultural commodities owned 18 sub-regency of Windusari, LQ $>1$ which means has advantages compared to the Magelang regency average. The highest value is at Pineapple LQ with 22.241 values. Generally LQ few plants in the Windusari which shows the value $>1$ respectively Rice, Cassava, Guava, Orange Tangerines, Jackfruit, Pineapple, Papaya, Banana, Rambutan, Sawo, Soursop, Breadfruit and Petai. Regarding Value of KS appears that the potential for specialization is not always indicated by the commodity with the highest LQ value.

\section{Conclusion}

Determination of agropolitan zone in Magelang regency is a crucial and strategic aspects of Magelang regency due to a buffering zone featured food and agribusiness in Central Java, where the biggest challenge is the potential of volcano disaster form of damage to agricultural infrastructure and material damage. Therefore, by referring to the aspect Availability Commodities, Adequacy of Plant Agriculture, and the safest distance from Volcanic Zone then defined the potential agropolitan competitive and have a relatively safe zone of potential Merapi volcano disaster. LQ and KS method show the superiority of sub-regency of Windusari as buffering food and agribusiness in Magelang regency. Similarly, the path length of the road infrastructure for accommodation and distribution of farm track which is the farthest distance from Mount Merapi.

\section{References}

1. Department of Health Magelang Regency, Retrieved from http://dinkes.magelangkab.go.id/, on September 7, 2017 (2013).

2. Department of Statistic Center of Magelang Regency, Retrieved from https://magelangkab.bps.go.id/, on September 7, 2017 (2016).

3. Surono, et al.,"The 2010 Explosive Eruption of Java's Merapi Volcano - a "100-year" event", Journal of Volcanology and Geothermal Research (2012).

4. R. Wimbardana, and S. Sagala, "Community Preparedness Against the Dangers of Cold Lava Mount Merapi”, Bumi Lestari Journal of Environment. 13 (2): 394-406 (2013).

5. R. Hendayana, Aplikasi Metode Location Quotient (LQ) dalam Penentuan Komoditas Unggulan, Bogor, Balai Pengkajian dan Pengembangan Teknologi Pertanian (2002).

6. Kompas, Erupsi Merapi 2010 Lebih Besar dari 1872, Retrieved from http://megapolitan.kompas.com/read/2010/11/09/15 573541/erupsi.merapi.2010.lebih.besar.dari.1872, on August 17, 2017 (2010).

7. Department of National Disaster Management, Retrieved from http://bpbd.magelangkab.go.id/v2/, on September 7, 2017 (2011). 